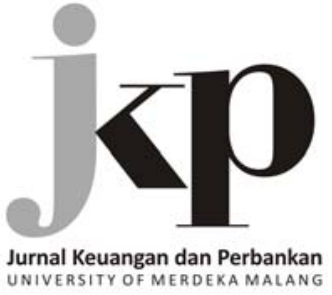

Article history:

Received: 2017-11-21

Revised: 2018-03-01

Accepted: 2018-04-13

\section{Robiyanto Robiyanto}

Department of Management

Faculty of Economics and Business

Satya Wacana Christian University

JI. Diponegoro 52-60, Salatiga

50711, Indonesia $\triangle$ Corresponding Author:

\section{Robiyanto Robiyanto:}

Tel. +62 298311881

Fax.+62 298321212

E-mail: robiyanto@staff.uksw.edu

This is an open access

article under the CC-BY-SA license

\section{Robiyanto Robiyanto (Indonesia) \\ The Dynamic Correlation between ASEAN-5 Stock Markets and World Oil Prices}

\begin{abstract}
Various studies on the relationship between world oil prices and stock markets that have been done previously mostly still done by using a static approach or an approach to test whether there is a short-term or long-term relationship. This research scrutinizes the dynamic relationship between world oil price change with the return of ASEAN's main stock markets such as Indonesia, Singapore, Malaysia, the Philippines, and Thailand by using Dynamic Conditional Correlation-Generalized Autoregressive Conditional Heteroscedasticity (DCCGARCH). The result shows that the correlation between world oil price's change with the return of ASEAN's main stock market was not static but change according to the stock market and commodity market's condition. During the normal period, DCC-GARCH is in the narrow range and stable, but during the period of stock market and commodity market turbulence, DCC-GARCH could alter extremely from positive to negative in some ASEAN countries. Generally, it is concluded that the use of static approach was not appropriate especially for rapidly changing in financial market and commodity market.
\end{abstract}

Keywords: ASEAN's Capital Markets; Dynamic Conditional Correlation-Generalized Autoregressive Conditional Heteroscedasticity (DCCGARCH); West Texas Intermediate (WTI)

\section{JEL Classification: G10; G15; Q41}

Citation: Robiyanto, R. (2018). The dynamic correlation between ASEAN-5 stock markets and world oil prices. Jurnal Keuangan dan Perbankan, 22(2), 198-210. https://doi.org/10.26905/jkdp.v22i2.1688

\begin{abstract}
Abstrak
Berbagai kajian mengenai hubungan perubahan harga minyak dunia dengan pasar saham yang telah dilakukan sebelumnya kebanyakan masih dilakukan dengan menggunakan pendekatan yang statis maupun pendekatan guna menguji ada tidaknya hubungan jangka pendek ataupun jangka panjang. Penelitian ini melakukan kajian hubungan perubahan harga minyak dunia dengan pasar saham-pasar saham pada negara-negara utama yang ada di kawasan ASEAN seperti pada negara Indonesia, Singapura, Malaysia, Filipina dan Thailand dengan menggunakan pendekatan Dynamic Conditional Correlation-Generalized Autoregressive Conditional Heteroscedasticity (DCC-GARCH). Penelitian ini menunjukkan bahwa korelasi antara pergerakan harga minyak dunia (WTI) tidaklah statis melainkan berubah seiring dengan kondisi yang terjadi pada pasar saham dan pasar komoditas. Pada kondisi normal, nilai DCC-GARCH cenderung berada pada kisaran yang sempit dan relatif stabil. Namun hal berbeda ditemukan pada saat terjadi gejolak pada pasar saham dan pasar komoditas pada saat tersebut terjadi perubahan DCC-GARCH yang sangat ekstrim dari sebelumnya positif menjadi negatif di beberapa negara seperti yang terjadi di Indonesia, Malaysia, dan Singapura, sedangkan pada negara lain seperti Thailand dan Filipina terjadi pelemahan hubungan dinamis. Secara umum disimpulkan bahwa penggunaan analisis hubungan yang statis tidaklah tepat terutama pada situasi pasar finansial dan komoditas yang berubah dengan cepat.
\end{abstract}

Kata Kunci: Pasar Modal di Kawasan ASEAN; Dynamic Conditional CorrelationGeneralized Autoregressive Conditional Heteroscedasticity (DCCGARCH); West Texas Intermediate (WTI) 
There are two types of oil which price is used as international references, West Texas Intermediate and Brent North Sea (Europe Brent) (Jarolimek et al., 2013; Klein, 2017). The former is used as a reference in the United States, and the latter is used in Europe. The fact is, West Texas Intermediate is often used as an international reference of oil price (Malkiel, 2011). Crude oil price movement is an important factor in the economy in general and companies in particular. This is based on the idea that oil is one of the main energy sources used by the industry, even, oil is seen as a major factor in determining the world stock price indexes (Souèek, 2013; Ratti \& Vespignani, 2015). Researchers such as Soytas et al. (2009), Le \& Chang (2011), and Guesmi \& Fattoum (2014) agreed that oil is a strategic commodity for the global economy and can affect the world economy (Papież \& Smiech, 2012; Creti, Ftiti, \& Guesmi, 2014).

Lin, Wesseh, \& Opiah (2014) stated that oil is the most important commodity in the global financial market, so when the world oil market and financial market are on the same period with high volatility, it is very possible to create shock transmission between those two markets. Oil price is determined by global request and demand. After the crash of oil price in 1970, many types of research were done to review the influence of oil price change on variables of the real sector of the economy. Most of those found that the crash of oil price influenced economy activities of developed and developing countries (Zhu, Li, \& Li, 2014). The studies on this field then were popular after the drastic increase of oil before the global financial crisis in 2008 because of the high demand of oil coming from Asia and the risk of geopolitics in the Middle East (Masih, Peters, \& Mello, 2010). The increase of oil demand from developing economy like China and India also influenced the oil price and the existence of oil substitution products (Henriques \& Sadorsky, 2008; Ramos \& Veiga, 2011).
In more detail, Lin, Wesseh, \& Opiah (2014) even argued that the movement of oil price impacts on stock price because it affects the cash flow and corporate earnings. So, the risk due to these changes of oil price is also an important matter for portfolio management (Morales, 2009; Sadorsky, 2014; Rahmanto, Riga, \& Indriana, 2016; Robiyanto, Wahyudi, \& Pangestuti, 2017a). The effect of oil price changes varies across different economic sectors (Arouri, Lahiani, \& Nguyen, 2011). Whereas, oil has ever been viewed as a non-agricultural commodity with the highest volatility since it reached $\$ 147 /$ barrel in July 2008 and dropped drastically to \$32/barrel in March 2009 (Hammoudeh et al., 2013). Consequently, this drastically change of oil price could be a threat for the world economy (Hamma, Jarboui, \& Gorbel, 2014) although the current crude oil price at the end of 2015 is stable at around $\$ 35-\$ 45 /$ barrel.

Some researchers even use a broader perspective by analyzing the relationship between oil price and economic variables such as GDP or production numbers like Hamilton (1983) who examined the relationship between oil price and the economy of the United States of America after the Second World War, Gisser \& Goodwin (1986) who conducted the same study by focusing on inflation and division of research periods after the Second World War. Both studies found that oil price fluctuations give impact on macroeconomic development and even may be the cause of the recession. Meanwhile, the impact of oil price changes on stock markets has also attracted attention from other researchers like Jones \& Paul (1996) who pioneered the study on the impact of oil price to the stock market. Jones \& Paul (1996) found that oil price movement has a negative association with the stock market in the US. This finding also supported by Filis, Degiannakis, \& Floros (2011). Meanwhile, Chkili, Aloui, \& Nguyen (2014) revealed that dynamic conditional correlation (DCC) between crude oil and US stock market 
return is influenced by various economic and geopolitical events.

In other stock market contexts like in South Korea, Masih, Peters, \& Mello (2010) found that South Korea stock market is influenced significantly by world oil price changes both in short and longterm. Whereas for the stock markets in Egypt, Oman, Saudi Arabia, and Kuwait, Abdelaziz, Chortareas, \& Cipollini (2008) discovered a relationship of oil with the capital markets. For the US capital markets, Jubinski \& Lipton (2013) concluded that the world oil price change gives significant effect on S\&P500 Index return. Is the ASEAN region, Hersugondo et al. (2015) conducted a research on the effect of the change of world oil price to the stock market return in several countries in ASEAN region. The research revealed that the world oil price change only has significant impacts on the return of stock markets in Malaysia and Thailand.

Various studies on the relationship of changes in world oil prices with stock markets that have been done previously mostly still used a static approach or an approach to test the availability of a shortterm or long-term relationship. There is some research such as Chkili, Aloui, \& Nguyen (2014), Arouri, Lahiani, \& Nguyen (2011), Filis, Degiannakis, \& Floros (2011), Nath, Bandopadhyay, \& Mondal (2014), and Arshad (2017), which uses dynamic relationship approach. Chkili, Aloui, \& Nguyen (2014) using the United States' stock market as the objects of study, while Filis, Degiannakis, \& Floros (2011) studies the dynamic correlation between oil price and stock market of oil-importing and oil-exporting countries. Meanwhile, Arouri, Lahiani, \& Nguyen (2011) using stock markets in Gulf Cooperation Council (GCC), Nath, Bandopadhyay, \& Mondal (2014) using Indian stock market, and Arshad (2017) using Islamic stock markets. The review with dynamic approach has never been done on the capital market in developing countries of
ASEAN (Hersugondo et al. (2015) used static approach). Therefore this study will review the relationship of world oil price change with the stock market in the main countries of ASEAN, such as Indonesia, Singapore, Malaysia, Philippines, and Thailand using a dynamic approach such as DCCGARCH. DCC-GARCH use in this study because the DCC-GARCH has proven can be successively estimated for large time-varying covariance matrices (Filis, Degiannakis, \& Floros 2011; Robiyanto, Wahyudi, \& Pangestuti, 2017b), even though there were some methods which could do so such as the Orthogonal-GARCH (Robiyanto, 2017), and the DCC-GARCH (Arouri, Lahiani, \& Nguyen, 2014).

\section{METHODS}

The data used in this study were the closing price of stock price from five capital markets in South East Asia (the members of ASEAN), Indonesia Stock Exchange (IDX) with Composite Stock Price Index (CSPI), Kuala Lumpur Stock Exchange (KLSE) with Kuala Lumpur Composite Index (KLCI), Stock Exchange Thailand (SET) with SET, Singapore Stock Exchange (SSX) with Strait Times, and Philippines Stock Exchange (PSE) with PSEi during period of January 1999-September 2015 and the closing oil price of West Texas Intermediate (WTI). The data of stock market price were gathered from Capital Market Statistic published by Financial Service Authority, while the data of WTI oil price were gathered from the official site of U.S. Energy Information Administration (U.S. EIA).

This study using WTI as a proxy of world oil price, because WTI highly correlated with OPEC price and Brent North Sea as seen in Table 1 and Figure 1. Klein (2017) also found that OPEC meeting could drive the long-term movements of WTI and Brent North Sea because both are driven by the same dynamics. 
Table 1. Correlation between WTI, Brent North Sea, and OPEC

\begin{tabular}{llrrr}
\hline & & WTI & OPEC & BRENT \\
\hline WTI & Pearson Correlation & 1 & $0.921^{* *}$ & $0.747^{* *}$ \\
& Sig. (2-tailed) & & 0.000 & 0.000 \\
& N & 153 & 153 & 153 \\
OPEC & Pearson Correlation & $0.921^{* *}$ & 1 & $0.794^{* *}$ \\
& Sig. (2-tailed) & 0.000 & & 0.000 \\
& N & 153 & 153 & 153 \\
BRENT & Pearson Correlation & $0.747^{* *}$ & $0.794^{* *}$ & 1 \\
& Sig. (2-tailed) & 0.000 & 0.000 & \\
& N & 153 & 153 & 153 \\
\hline
\end{tabular}

**. Correlation is significant at the 0.01 level (2-tailed).

Source: https://www.eia.gov/ and http://www.opec.org/basket/ basketDayArchives.xml, processed

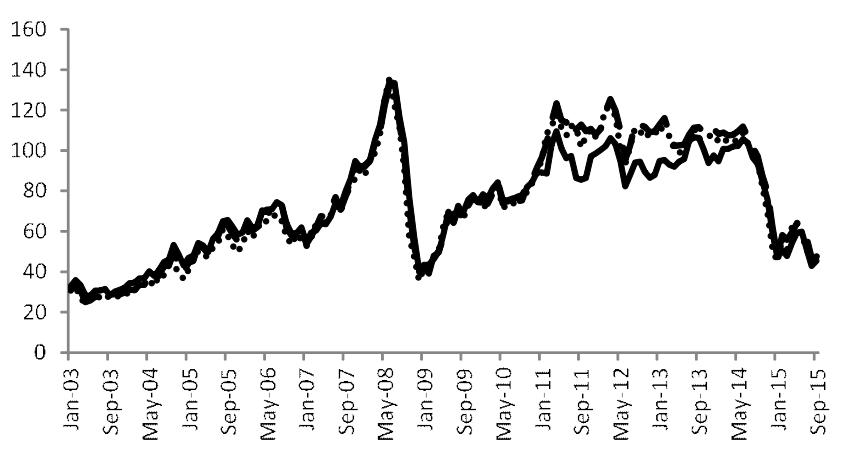
-WTI - Brent $\cdots . .$. OPEC

Figure 1. WTI, Brent North Sea, and OPEC's Oil Price Movements

Return of stock market was observed using:

$$
\mathrm{R}_{\mathrm{m}, \mathrm{t}}=\left[\frac{\text { Composite }_{\mathrm{t}}-\text { Composite }_{\mathrm{t}-1}}{\text { Composite }_{\mathrm{t}-1}}\right]
$$

Where:

$\begin{aligned} \text { Composite }_{\mathrm{t}}= & \begin{array}{l}\text { closing of stock price index ob- } \\ \text { served in } \mathrm{t} \text { month }\end{array} \\ \text { Composite }_{\mathrm{t}-1}= & \begin{array}{l}\text { closing of stock price index ob- } \\ \text { served in } \mathrm{t}-1 \text { month }\end{array}\end{aligned}$

While the return of world oil price was counted using:

$$
\mathrm{R}_{\mathrm{WTI}, \mathrm{t}}=\left[\frac{W T I_{\mathrm{t}}-\mathrm{WTI}_{\mathrm{t}-1}}{W T I_{\mathrm{t}-1}}\right]
$$

Where:

$\mathrm{WTI}_{\mathrm{t}}=$ closing price of WTI oil spot in $\mathrm{t}$ month

$\mathrm{WTI}_{\mathrm{t}-1}=$ closing price of WTI oil spot in $\mathrm{t}-1$ month

\section{The Dynamic Approach using DCC-GARCH} (Dynamic Conditional Correlation-Generalized Autoregressive Conditional Heteroscedasticity)

The model of DCC-GARCH was introduced by Engle (2002) with the following specification:

$$
\begin{aligned}
& r_{t} \mid={ }_{t-1} \sim N\left(0, D_{t} R_{t} D_{t}\right), \\
& D_{t}^{2}=\operatorname{diag}\left\{\omega_{i}\right\}+\operatorname{diag}\left\{\kappa_{i}\right\}^{\circ} r_{t-1} r_{t-1}^{\prime}+\operatorname{diag}\left\{\lambda_{i}\right\}^{\circ} D_{t-1}^{2}, \\
& \varepsilon_{t}=D_{t}^{-1} r_{t,} \\
& Q_{t}=S^{\circ}\left(\imath \imath^{\prime}-A-B\right)+A^{\circ} \varepsilon_{t-1} \varepsilon_{t-1}^{\prime}+B^{\circ} Q_{t-1}, \\
& R_{t}=\operatorname{diag}\left\{Q_{i}\right\}^{-1} Q_{t} \operatorname{diag}\left\{Q_{i}\right\}^{-1} .
\end{aligned}
$$

Log likelihood or estimator can be shown as below:

$$
\begin{aligned}
& \begin{aligned}
& r_{t} \mid={ }_{t-1} \sim N\left(0, H_{t}\right), \\
& \mathrm{L} \quad=-\frac{1}{2} \sum_{t=1}^{T}\left(n \log (2 \pi)+\log \left|H_{t}\right|+r_{t}^{\prime} H_{t}^{-1} r_{t}\right) \\
& \quad=-\frac{1}{2} \sum_{t=1}^{T}\left(n \log (2 \pi)+\log \left|D_{t} R_{t} D_{t}\right|+r_{t}^{\prime} D_{t}^{-1} R_{t}^{-1} D_{t}^{-1} r_{t}\right) \\
& \quad=-\frac{1}{2} \sum_{t=1}^{T}\left(n \log (2 \pi)+2 \log \left|D_{t}\right|+\log \left|R_{t}\right|+\varepsilon_{t}^{\prime} R_{t}^{-1} \varepsilon_{t}\right) \\
&=-\frac{1}{2} \sum_{t=1}^{T}\left(n \log (2 \pi)+2 \log \left|D_{t}\right|+r_{t}^{\prime} D_{t}^{-1} D_{t}^{-1} r_{t}-\varepsilon_{t}^{\prime} \varepsilon_{t}+\log \left|R_{t}\right|+\varepsilon_{t}^{\prime} R_{t}^{-1} \varepsilon_{t}\right),
\end{aligned}
\end{aligned}
$$

Which simply can be maximized to the parameter of the model. One of the purposes of this model formulization was in order to make it easier to predict through the matrix of co-variants is really big. Newey \& McFadden (1994) argued that the formulation of model was done into deep the consistency and asymptotic normality of those parameters qualified. If $\mathrm{D}$ parameter is noted with $\phi$ and additional 
parameter in $\mathrm{R}$ is noted with $\theta$, the Log-likelihood can be stated as number of partial volatilities and correlation as follows $\mathrm{L}(\theta, \phi)=\mathrm{L}_{\mathrm{V}}(\theta)+\mathrm{L}_{\mathrm{C}}(\theta, \phi)$

The term of volatilities is as follows:

$L_{V}(\theta)=-\frac{1}{2} \sum_{t}\left(n \log (2 \pi)+\log \left|D_{t}\right|^{2}+r_{t}^{\prime} D_{t}^{-2} r_{t}\right)$

Components of correlation are:

$L_{C}(\theta, \phi)=-\frac{1}{2} \sum_{t}\left(\log \left|R_{t}\right|+\varepsilon_{t}^{\prime} R_{t}^{-1} \varepsilon_{t}-\varepsilon_{t}^{\prime} \varepsilon_{t}\right)$

Partial volatilities of likelihood are the number of likelihood GARCH in individual

$$
L_{V}(\theta)=-\frac{1}{2} \sum_{t} \sum_{i=1}^{n}\left(\log (2 \pi)+\log \left(h_{i, t}\right)+\frac{r_{i, t}^{2}}{h_{i, t}}\right)
$$

Which if they are combined, they can be maximized by optimizing each term. The second part of likelihood was done to estimate the correlation parameter. Considering this squared residual was not tied to these parameters, so those things cannot be involved in the first order condition and must be ignored. The estimator resulted then was called DCC LL INT because it used integrated model. The two-steps approach to optimize likelihood was used to produce:

$\hat{\theta}=\arg \max \left(L_{V}(\theta)\right) \mid$

The value was then used in the second step: $\max _{\phi}\left\{L_{C}(\hat{\theta}, \phi)\right\}$.

The DCC-GARCH model has also been used by Robiyanto, Wahyudi, \& Pangestuti (2017b) in studying the dynamic relationship between the Indonesian stock market and the Malaysian stock market with the price of gold. While the variation of GARCH model such as OGARCH (Orthogonal Generalized Autoregressive Conditional Hete- roscedasticity) also been used by Robiyanto (2017). This study does not use panel GARCH proposed by Cermeño \& Grier (2001), because this study tries to test the time-varying correlation for single time series for each stock market studied.

\section{RESULTS}

\section{The Result of Stationary Data Test}

The test of stationary data was done with Augmented Dickey-Fuller (ADF) test and can be seen in Table 2. Based on the table, it can be concluded that all the values of Augmented DickeyFuller Statistic on return (first difference), all variables reviewed are significant at the level of significance 1 percent showing that all the data used are stationer.

Table 2. Test Result of Augmented Dickey-Fuller on Return (First Difference)

\begin{tabular}{lc}
\hline \multicolumn{1}{c}{ Variables } & Augmented Dickey-Fuller Statistics \\
\hline JCI & $-11.14609^{*}$ \\
KLSE & $-13.63235^{*}$ \\
PSE-i & $-18.02572^{*}$ \\
SET & $-13.59060^{*}$ \\
STI & $-12.55380^{*}$ \\
WTI & $-10.79896^{*}$ \\
\hline
\end{tabular}

Note: ${ }^{*}$ statistical significance at the 1 percent

\section{The Result of ARCH Test}

The result of ARCH test is shown in Table 3. Only PSE-i produce the $\mathrm{F}$ value which is significant at the 1 percent significance level.

Table 3. Test Result of ARCH Test

\begin{tabular}{lcc}
\hline Variables & F & Prob. $\mathbf{F}$ \\
\hline JCI & 0.993985 & 0.3200 \\
KLSE & 4.313355 & 0.0391 \\
PSE-i & $15.50784^{*}$ & 0.0001 \\
SET & 0.085039 & 0.7709 \\
STI & 2.175431 & 0.1418 \\
\hline
\end{tabular}

Note: ${ }^{*}$ statistical significance at the 1 percent 


\section{Time-Varying Correlation between WTI and ASEAN-5 Stock Markets}

The time-varying correlation of JCI-WTI change along with the time, and it is proven by the time-varying correlation changing between -0.42891 to 0.483525 during the period of observation as seen in Figure 1. The highest value of the time-varying correlation between JCI-WTI was 0.483525 happening in the mid of 2008 when there was commodity boom before crash due to the subprime mortgage crisis, while the highest negative value of the timevarying correlation happened after subprime mortgage crisis when there was a decrease of commodities price significantly. When subprime mortgage crisis got calmer, the time-varying correlation started to be stable. Some main events in Indonesia have a mild effect on the time-varying correlation. Some main events in Indonesia are shown in Table 4 . The different thing happened to the time-varying correlation of KLSE-WTI as seen in Figure 2.

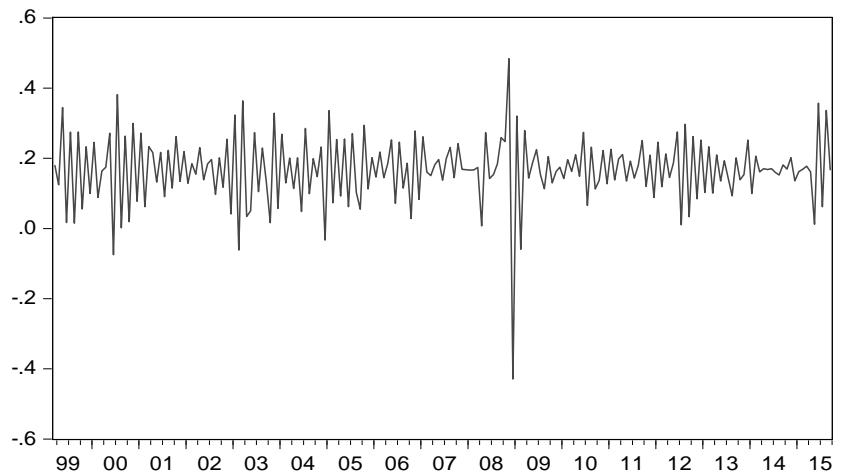

Figure 2. Time-Varying Correlation between JCI-WTI
The values of the time-varying correlation of KLSE-WTI ranged between -0.02086 to 0.490699 . Malaysia which is the producer of commodities like $\mathrm{CPO}$ was also affected by commodity boom, so the highest values of the time-varying correlation KLSEWTI was 0.490699 , and it happened at the peak of the commodity boom. But when there was subprime mortgage crisis, the values of the time-varying correlation of KLSE-WTI did not change as drastically as the time-varying correlation of JCI-WTI. The values of the time-varying correlation of KLSE-WTI only changed to not correlated with -0.02086 . As what happened in Indonesia, the value of the timevarying correlation of KLSE-WTI turned stable when subprime mortgage crisis decreased, with some political events that could affect the time-varying correlation of KLSE-WTI as shown in Table 5.

Quite a different thing was found at the timevarying correlation of PSEi-WTI, the values of the time-varying correlation of PSEi-WTI were on the range of -0.95132 to 0.541471 as seen in Table 3 . When there was commodity boom, the values of the time-varying correlation of PSEI-WTI tend to increase gradually along the period and reached 0.541471 , after subprime mortgage crisis, the values of the time-varying correlation of PSEi-WTI decreased gradually. In 2015, the time-varying correlation of PSEi-WTI became stronger negative ones. One possible explanation is the occurrence of the unsecured situation caused by massive terrorist acts in the Philippines in the year 2015. The main events in the Philippines are shown in Table 6.

Table 4. Main Events in Indonesia

\begin{tabular}{lc}
\hline \multicolumn{1}{c}{ Event } & Year \\
\hline Two financial scandals dog the Wahid administration: Buloggate (embezzled funds from the state & 2000 \\
logistics agency), and Bruneigate (missing humanitarian aid funds from the Sultan of Brunei). & 2002 \\
East Timor becomes independent. & 2002 \\
A bomb attack on the Kuta Beach nightclub district of Bali kills 202 people, most of them tourists. & \\
Widodo's Administration & 2013 \\
Brazil and the Netherlands recalled their ambassadors from Indonesia after the execution by firing & 2015 \\
squad of two of their citizens for drug trafficking. & \\
Australia recalls ambassador after Indonesia executes two Australian drug convicts, in a group also & \\
including three Nigerians, an Indonesian, a Brazilian and a Ghanaian.
\end{tabular}

Source: BBC (2018a) 


\begin{tabular}{lc}
\hline \multicolumn{1}{c}{ Event } & Year \\
\hline $\begin{array}{l}\text { Prime Minister Mahathir Mohamad sacked his deputy and presumed successor, Anwar Ibrahim, on } \\
\text { charges of sexual misconduct, against the background of differences between the two men over economic } \\
\text { policy; Ibrahim arrested. }\end{array}$ & 1998 \\
Prime Minister Abdullah Badawi wins landslide general election victory. Former deputy PM Anwar & 2004 \\
lbrahim freed after court overturns his sodomy conviction. Scores of Malaysians die in Asian tsunami & \\
disaster. Malaysia delays planned deportations of many thousands of illegal immigrants, most of them & \\
from Indonesia. & 2007 \\
Anwar Ibrahim's Parti Keadilan Rakyat loses a bitterly contested by-election to the government. The & 2008 \\
result is seen as a blow to his efforts to revive his political career. & \\
Prime Minister Abdullah Ahmad Badawi's National Front coalition suffers its worst election result in \\
decades, losing its two-thirds parliamentary majority and control of five state assemblies. Opposition \\
leader Anwar Ibrahim is arrested over allegations of sodomy, in a move that exacerbates political \\
tensions. \\
$\begin{array}{l}\text { Police use tear gas and water cannon to disperse thousands of people taking part in Kuala Lumpur rally } \\
\text { calling for electoral reform. PM Razak announces setting-up of a parliamentary committee to study } \\
\text { electoral reform. }\end{array}$ \\
$\begin{array}{l}\text { Opposition leader Anwar Ibrahim is jailed for five years after failing to win an appeal against a sodomy } \\
\text { conviction. }\end{array}$ \\
$\begin{array}{l}\text { Police arrest opposition politician Nurul Izzah Anwar, the eldest daughter of jailed opposition leader } \\
\text { Anwar Ibrahim, for alleged sedition over a speech she made in parliament. }\end{array}$ \\
Anwar Ibrahim is denied royal pardon to overturn sodomy conviction and loses his seat as an MP. \\
\hline
\end{tabular}

Source: BBC (2018b)

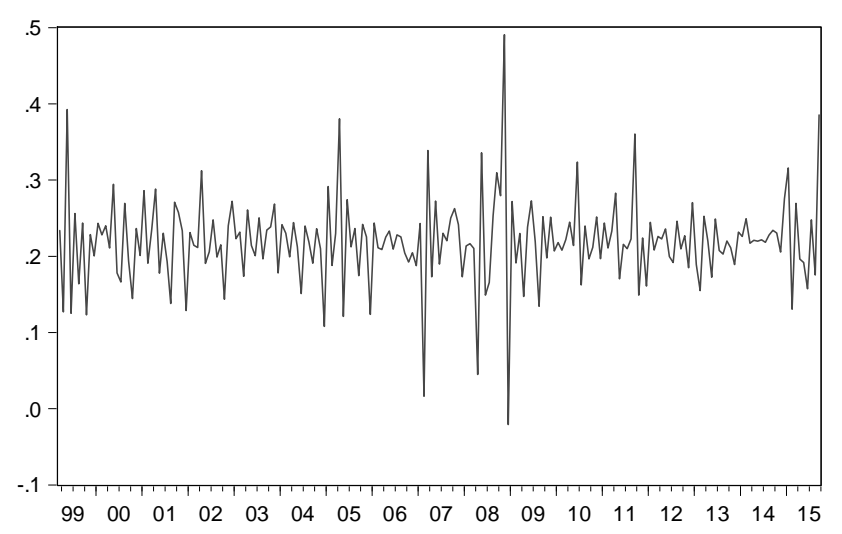

Figure 3. Time-Varying Correlation between KLSE-WTI

The values of the time-varying correlation of SET-WTI were relatively at a narrow range of 0.069808 to 0.234671 as seen in Figure 4. It was because Thailand is not a country depending on oil commodity. When there was commodity boom, the time-varying correlation of SET-WTI was also on the narrow range and had a weak relation. It was getting weaker when subprime mortgage crisis and started to be stable after subprime mortgage crisis despite some gloomy political events has occurred in Thailand as seen in Table 7. On the other side, the patterns of the time-varying correlation of STIWTI were relatively similar to ones of the time-varying correlation of JCI-WTI. The values of the timevarying correlation of STI-WTI were on a wide range of -0.60012 to 0.735596 as seen in Figure 5 . When the period of the commodity boom, the values of the time-varying correlation of STI-WTI were relatively stable, but the values of the time-varying correlation of STI-WTI turned to negative with stronger relation after subprime mortgage crisis and became stable until 2014. 
Table 6. Main Events in the Philippines

\begin{tabular}{l}
\hline \multicolumn{1}{c}{ Event } \\
\hline Impeachment proceedings start against President Estrada on allegations of corruption, betrayal of public \\
trust, and violation of the constitution \\
Suspension of impeachment causes mass street protests. Military withdraws support, and President \\
Estrada stands down. Vice-President Gloria Arroyo was sworn in as president. \\
Series of deadly bomb blasts on Manila bus and three locations in Zamboanga city blamed on Islamist \\
militants. \\
Gloria Arroyo wins May's presidential elections. \\
Forty-four police commandos are killed in clashes with Muslim rebels on the southern island of \\
Mindanao, the largest loss of life for the security forces in recent memory. \\
\hline
\end{tabular}

Source: BBC (2018c)

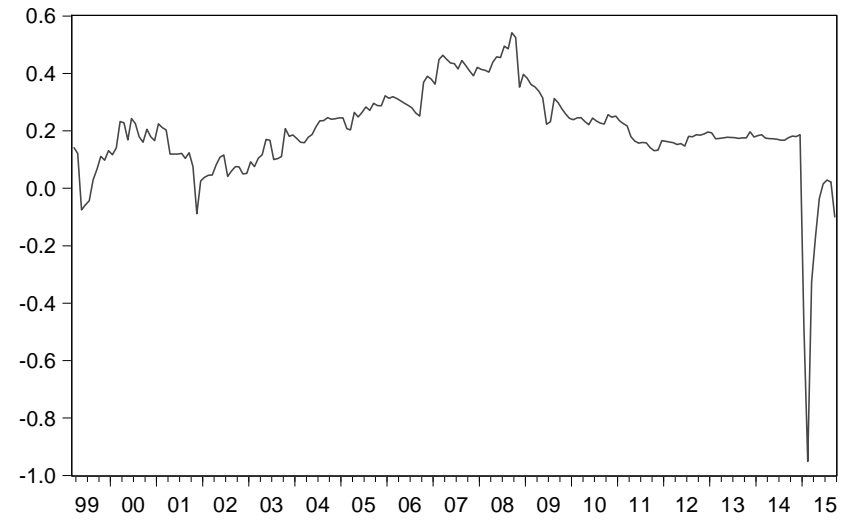

Figure 4. Time-Varying Correlation PSEi-WTI

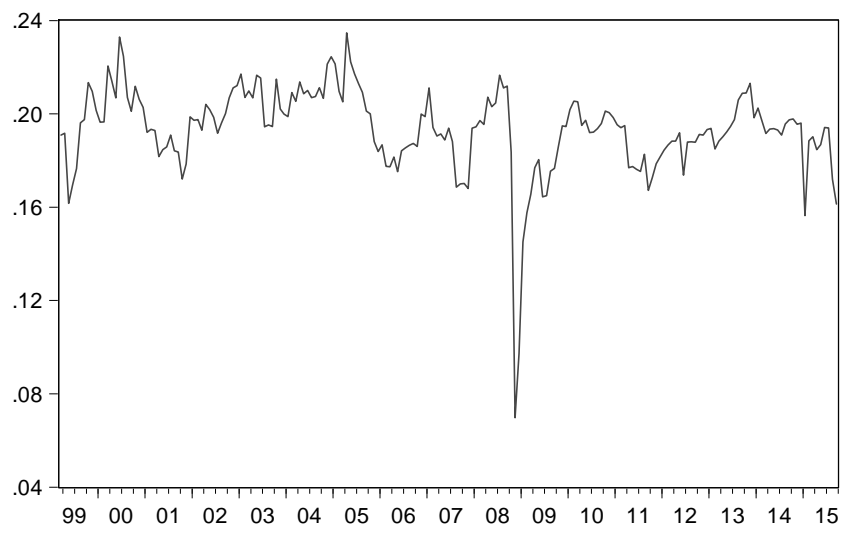

Figure 5. Time-Varying Correlation between SET-WTI
Going to 2015, the time-varying correlation of STI-WTI became fluctuation with a wide range. It happened because as the country with the better capital market than others in ASEAN, Singapore capital market is really sensitive to financial policy in global level as Federal Reserve policy and this uncertainty affected the capital market of Singapore. While the fluctuation of WTI, at the same time also caused fluctuation in the time-varying correlation of STI-WTI because many oil companies supplied ASEAN market operating in Singapore. Also, some political uncertainty raised in Singapore during 2015 as shown in Table 8 .

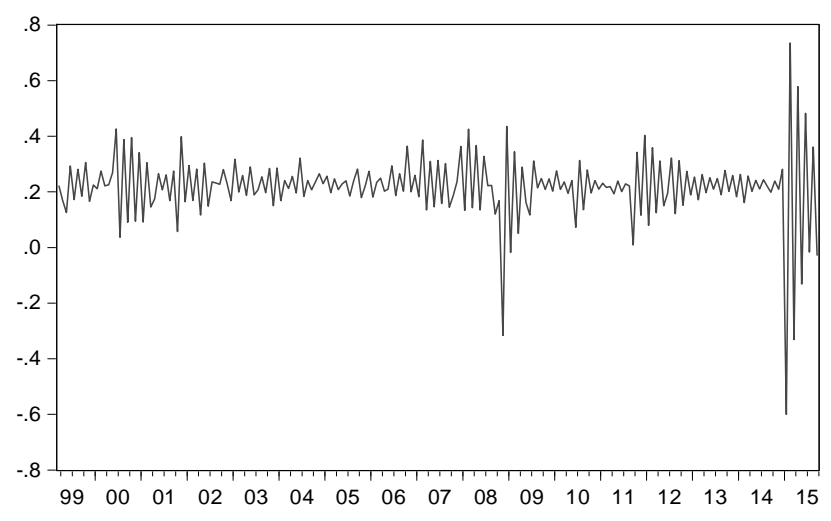

Figure 6. Time-varying correlation between STI-WTI 


\section{Jurnal Keuangan dan Perbankan | KEUANGAN}

Vol. 22, No. 2, April 2018: 198-210

Table 7. Main Events in Thailand

\begin{tabular}{l} 
Year \\
\hline New Thai Love Thai party wins elections after a partial re-run of the poll. Leader Thaksin Shinawatra \\
forms a coalition government. \\
Thaksin Shinawatra begins a second term as PM after his party wins February's elections by a landslide. \\
As violent unrest continues in the south, Prime Minister Thaksin is given new powers to counter \\
suspected Muslim militants in the region. In November the death toll in violence since January 2004 \\
tops 1,000. \\
Military leaders stage a bloodless coup while Prime Minister Thaksin Shinawatra is at the UN General \\
Assembly. Retired General Surayud Chulanont is appointed as interim prime minister in October. \\
General elections mark the first major step towards a return to civilian rule. The People Power Party \\
(PPP), seen as the reincarnation of Thaksin's Thai Rak Thai (Thais Love Thais) party, wins the most \\
votes. \\
Return to civilian rule. Samak Sundaravej of the Thaksin-linked People Power Party (PPP) is sworn in \\
as prime minister. Ousted premier Thaksin Shinawatra returns from exile. \\
Opposition protesters occupy Bangkok's main government complex and begin mass anti-government \\
protests calling for the resignation of Prime Minister Samak Sundaravej. \\
The pro-Thaksin Pheu Thai party wins a landslide victory in elections. Yingluck Shinawatra - the sister \\
of Mr. Thaksin Shinawatra - becomes prime minister. \\
Constitutional court orders Prime Minister Yingluck Shinawatra and several ministers out of office over \\
alleged irregularities in appointment of security adviser. \\
Coup leader General Prayuth Chan-Ocha is made prime minister. \\
Coup-appointed Prime Minister Prayuth Chan-Ocha ends martial law, continues to rule by executive \\
order.
\end{tabular}

Source: BBC (2018e)

Table 8. Main Events in Singapore

\begin{tabular}{|c|c|}
\hline Event & Year \\
\hline Unprecedented anti-government rally - the first legal demonstration outside an election campaign. & 2001 \\
\hline Lee Hsien Loong, the eldest son of former Prime Minister Lee Kuan Yew, is sworn in as prime minister. & 2004 \\
\hline $\begin{array}{l}\text { Lee Hsien Loong's ruling People's Action Party wins general elections which are seen as the first real test } \\
\text { of the prime minister's popularity. }\end{array}$ & 2006 \\
\hline $\begin{array}{l}\text { Prime Minister Lee Hsien Loong unveils stiffer measures against corruption after a number of high- } \\
\text { profile graft scandals in the last two years. }\end{array}$ & 2015 \\
\hline
\end{tabular}

Source: BBC (2018d)

Table 9. Main Events and Their Corresponding Oil Price Shock Origin

\begin{tabular}{lrl}
\hline \multicolumn{1}{c}{ Event } & \multicolumn{1}{c}{ Year } & \multicolumn{1}{c}{ Oil Price Shock Origin } \\
\hline Several oil production cuts by OPEC & $1998-1999$ & Supply side \\
Housing market boom & 2000 & Aggregate demand side \\
9/11 terrorist attack in the US & 2001 & Precautionary demand \\
PdVSA worker's strike & 2002 & Supply side \\
The second war in Iraq & 2003 & Precautionary demand \\
Chinese economic growth & $2006-2007$ & Aggregate demand side \\
Global financial crisis & 2008 & Aggregate demand side \\
\hline
\end{tabular}

Source: Filis, Degiannakis, \& Floros (2011) 
In Table 10, it can be seen that the values of the time-varying correlation from WTI with capital market in ASEAN. This study also supports Filis, Degiannakis, \& Floros (2011), which shows that some main events could have any impact on oil price shock as shown in Table 9.

Table 10. Time-Varying Correlation between WTI and ASEAN5 Stock Markets

\begin{tabular}{lrrr}
\hline & Mean & Maximum & \multicolumn{1}{c}{ Minimum } \\
\hline JCI-WTI & 0.167456 & 0.483525 & -0.42891 \\
KLSE-WTI & 0.219421 & 0.490699 & -0.02086 \\
PSEi-WTI & 0.197605 & 0.541471 & -0.95132 \\
SET-WTI & 0.193286 & 0.234671 & 0.069808 \\
STI-WTI & 0.218220 & 0.735596 & -0.60012 \\
\hline
\end{tabular}

\section{DISCUSSION}

The findings of the time-varying correlation values that have wide range in this research prove that static analysis of relationship is not accurate to review the relations between stock market change and world oil price change as stated Jones \& Paul (1996), Abdelaziz, Chortareas, \& Cipollini (2008), and Masih, Peters, \& Mello (2010). By using dynamic approach, it can be found that there is a change in the strength of relations along with the situation and condition happen in capital market and commodities.

Every capital market reviewed in this research has different strength and dynamic relation patterns. This can happen because every country has a different level of dependency on world oil price. These findings also show different result from Hersugondo et al. (2015), which using static approach. Hersugondo et al. (2015) concluded that WTI change did not give significant effect on the stock market of Malaysia and Thailand. In this research found that the values of the time-varying correlation of KLSE-WTI even reached 0.490699 before subprime mortgage crisis which means there had been a strong relation between KLSE-WTI before it happened. In the case of Thailand capital market, the findings show that the values of the time-varying correlation of SET-WTI were relatively lower meaning that the dynamic relation of SET-WTI was relatively weak. Overall, the finding shows that main event such as subprime mortgage crisis has a huge impact on the time-varying correlation between ASEAN's stock market and WTI. This finding supports Arouri, Lahiani, \& Nguyen (2011) and Filis, Degiannakis, \& Floros (2011). This finding also supports Morales \& Andreosso-O'Callaghan (2014), Sadorsky (2014), and Hersugondo et al. (2015), who argued that the movement of oil price impacts on stock price because it affects the cash flow and corporate earnings, especially for oil importing countries and oil consuming countries.

\section{CONCLUSION AND SUGGESTIONS}

\section{Conclusion}

The study scrutinizes the time-varying correlation between ASEAN-5 stock markets and oil price. DCC-GARCH by Engle (2002) was used to estimate the conditional correlation. The finding provides evidence that time-varying correlation of ASEAN-5 stock markets and world oil price differs for each country.

In normal condition, DCC-GARCH values tend to be at narrow range and relatively stable. Different things are found when there is a wave in the stock market and commodities like when the global financial crisis (subprime mortgage crisis) happened in the United States. At that moment, DCC-GARCH changed extremely from positive to negative in some countries such as Indonesia, Malaysia, and Singapore, while in other countries like Thailand and Philippines, there was the decrease of a dynamic relationship. These findings partially agree with Filis, Degiannakis, \& Floros (2011), which found that economic crisis such as sub-prime crisis could trigger a stronger positive correlation between the stock market and oil price. 


\section{Suggestions}

This study using only the bivariate model, so it could not capture any exogenous variables. Further research may use the multivariate model that will able to explain any effect of other exogenous variables such as macroeconomic variables. Dynamic panel GARCH combined with DCC also suggested using in further research in order to generalize the finding across ASEAN-5 countries.
For the investors or traders in stock market or commodities, they are suggested to create trading strategies or compiling portfolios actively to catch up with the dynamics of markets to reach the goal of investment. Investors and traders must be aware also that the oil price's movement has an impact on stock price. Oil price factor must become an important matter for portfolio management.

\section{REFERENCES}

Abdelaziz, M., Chortareas, G., \& Cipollini, A. (2008). Stock prices, exchange rates, and oil: Evidence from Middle East oilexporting countries. Working Paper.

Arouri, M. E. H., Lahiani, A., \& Nguyen, D. K. (2011). Return and volatility transmission between world oil prices and stock markets of the GCC countries. Economic Modelling, 28(4),1815-1825.

Arouri, M. E. H., Lahiani, A., \& Nguyen, D. K. (2014). World gold prices and stock return in China: Insights for hedging and diversification strategies. HAL Working Paper.

Arshad, S. 2017. Analysing the relationship between oil prices and Islamic stock markets. Economic Papers: A journal of applied economics and policy, 36(4), 429-443.

BBC. 2018. Indonesia profile - Timeline 2018a [cited March 13, 2018]. Available from http:// www.bbc.com/news/worldasia-pacific-15114517.

BBC. 2018. Malaysia profile - Timeline 2018b [cited March 13, 2018]. Available from http:// www.bbc.com/news/worldasia-pacific-15391762.

BBC. 2018. Philippines profile - Timeline 2018c [cited March 13, 2018]. Available from http:// www.bbc.com/news/worldasia-15581450.

BBC. 2018. Singapore profile - Timeline 2018d [cited March 13, 2018]. Available from http:// www.bbc.com/news/worldasia-15971013.

BBC. 2018. Thailand profile - timeline 2018e [cited March 13, 2018]. Available from http:// www.bbc.com/news/worldasia-15641745.

Cermeño, R., \& Grier, K. B. (2001). Modeling GARCH Processes in Panel Data: Theory, Simulations, and Examples. The University of Oklahoma.

Chkili, W., Aloui, C., \& Nguyen D. K. (2014). Instabilities in the relationships and hedging strategies between crude oil and US stock markets: Dolong memory and asymmetry matter? Journal of International Financial Markets, Institutions, and Money, 33, 354-366.

Creti, A., Ftiti, Z., \& Guesmi, K. (2014). Oil price and financial markets in the main OPEC countries.
Energy Studies Review Special Issue.

Engle, R. F. (2002). Dynamic conditional correlation: A simple class of multivariate generalized autoregressive conditional heteroskedasticity models. Journal of Business $\mathcal{E}$ Economic Statistics, 20(3), 339-350.

Filis, G., Degiannakis, S., \& Floros, C. (2011). Dynamic correlation between stock market and oil prices: The case of oil-importing and oil-exporting countries. International Review of Financial Analysis, 20(3), 152-164.

Gisser, M., \& Goodwin, T. H. (1986). Crude oil and the macroeconomy: Tests of some popular notions: Note. Journal of Money, Credit, and Banking, 18(1), 95-103.

Guesmi, K., \& Fattoum, S. (2014). Return and volatility transmission between oil prices and oil-exporting and oil-importing countries. Economic Modelling, 38, 305-310.

Hamilton, J. D. (1983). Oil and the macroeconomy since world war II. Journal of Political Economy, 91(2), 228-248.

Hamma, W., Jarboui, A., \& Ghorbel, A. (2014). Effect of oil price volatil- 


\section{The Dynamic Correlation between ASEAN-5 Stock Markets and World Oil Prices}

Robiyanto Robiyanto

ity on Tunisian Stock Market at sector-level and effectiveness of hedging strategy. Procedia Economics and Finance, 13, 109-127.

Hammoudeh, S., Liu, T., Chang, C. L., \& McAleer, M. (2013). Risk spillovers in oil-related CDS, stock, and credit markets. Energy Economics, 36, 526-535.

Henriques, I., \& Sadorsky, P. (2008). Oil prices and the stock prices of alternative energy companies. Energy Economics, 30(3), 998-1010.

Hersugondo, S., Robiyanto, R., Wahyudi, S., \& Muharam, H. (2015). The world oil price movements and stock returns in several Southeast Asia's capital markets. International Journal of Applied Business and Economic Research, 13(2), 527-534.

Jarolimek, A., Lorusso, J., Walsh, T., \& Yudin, P. (2013). Oil: A statistical analysis of West Texas intermediate and brent crude. Financial Markets $\mathcal{E}$ Instruments Professor Goldstein.

Jones, C. M., \& Paul, G. (1996). Oil and the stock markets. Journal of Finance, 51(2), 463-491.

Jubinski, D., \& Lipton, A. F. (2013). VIX, gold, and oil: How do commodities react to financial market volatility. Journal of Accounting and Finance, 13(1), 70-88.

Klein, T. 2017. Trend contagion in WTI and brent crude oil spot and futures prices-A spread and correlation analysis. Meeting the Energy Demands of Emerging Economies, 40th IAEE International Conference: International Association for Energy Economics.

Le, T.-H., \& Chang, Y. (2011). Dynamics between strategic commodities and financial variables. Economic Growth Centre Working Paper.

Lin, B., Wesseh, P. K., \& Appiah, M. O. (2014). Oil pricefluctuation, volatility spillover, and the Ghanaian equity market: Implication for portfolio management and hedging effectiveness. Energy Economics, 42, 172-182.

Malkiel, B. G. (2011). The efficient market hypothesis and the financial crisis. Working Paper.

Masih, R., Peters,S., \& Mello, L. D. (2010). Oil price volatility and stock price fluctuations in an emerging market: Evidence from South Korea. Working Paper.

Morales, L. (2009). Interlinkages Between equity, currency, precious metals and oil markets: An emphasis on emerging markets. Dissertation. The University of Limerick.

Morales, L., \& AndreossoO'Callaghan, B. (2014). Volatility Analysis of precious metals returns and oil returns: An ICSS approach. Journal of Economics and Finance, 38(3), 492-517.

Nath, S. T., Bandopadhyay, K., \& Mondal, D. (2014). An empirical study on the dynamic relationship between oil prices and Indian stock market. Managerial Finance, 40(2), 200-215.

Newey, W., \& McFadden, D. (1994). Large sample estimation and hypothesis testing. Handbook of Econometrics, 2113-2245.

Papież, M., \& Śmiech, S. (2012). Causality in mean and variance between returns of crude oil and metal prices, agricultural prices and financial market prices. Paper read at 30th International Conference Mathematical Meth- ods In Economics, at Karviná: Silesian University, School of Business Administration.

Rahmanto, F., Riga, M. H., \& Indriana, V. (2016). The effects of crude oil price changes on the Indonesian Stock Market: A sector investigation. Indonesian Capital Market Review, 8, 12-22.

Ramos, S. B., \& Veiga, H. (2011). Risk factors in oil and gas industry return: International evidence. Energy Economics, 33(3), 525542.

Ratti, R. A., \& Vespignani, J. L. (2015). OPEC and non-OPEC oil production and the global economy. Energy Economics, 50, 364-378.

Robiyanto, R. 2017. The analysis of capital market integration in ASEAN Region by using the OGARCH approach. Jurnal Keuangan dan Perbankan, 21(2), 169-175.

Robiyanto, R., Wahyudi, S., \& Pangestuti, I. R. D. (2017a). Testing commodities as safe haven and hedging instrument on ASEAN's five stock markets. Jurnal Ekonomi Kuantitatif Terapan, 10(2), 231-238.

Robiyanto, R., Wahyudi, S., \& Pangestuti, I. R. D. (2017b). The volatility-variability hypotheses testing and hedging effectiveness of precious metals for the Indonesian and Malaysian capital markets. Gadjah Mada International Journal of Business, 19(2), 167-192.

Sadorsky, P. (2014). Modeling volatility and correlations between emerging market stock prices and the prices of copper, oil, and wheat. Energy Economics, $43,72-81$. 


\section{Jurnal Keuangan dan Perbankan | KEUANGAN}

Vol. 22, No. 2, April 2018: 198-210

Souèek, M. (2013). Crude oil, equity, and gold futures open interest co-movements. Energy Economics, 40, 306-315.
Soytas, U., Sari, R., Hammoudeh, S., \& Hacihasanoglu, E. (2009). World oil prices, precious metal prices and macroeconomy in Turkey. Energy Policy, 37(12), 5557-5566.
Zhu, H.-M., Li, R., \& Li, S. (2014). Modeling dynamic dependence between crude oil prices and AsiaPacific stock market returns. International Review of Economics and Finance, 29, 208-223. 